part of a child's skeleton embedded in hard travertine.

The block containing the child was hewn out and sent to the Museum of the Royal College of Surgeons, London, where the encrusting rock was successfully chiselled away from the skeleton by Ernest Smith. The extraction involved three months of delicate manipulation. It was then seen that the child had been buried in a sitting posture, heels under the buttocks, back flexed, and head thrust down on the breast. The child had been about four years of age and a little more than three feet in stature, being of slender build. Unfortunately, the face had been smashed after burial and the teeth were found scattered near the skull. The teeth left no doubt as to the racial nature of the child; they had the characteristic Neanderthalian traits. So, too, had the temporal bones. The frontal bone was damaged, but the hinder part of the skull-the part missing in the Galilee skullwas intact and well preserved.

Mr. McCown joined Sir Arthur Keith in January of the present year to complete an investigation of the anatomical details and draw up a report. The hinder part of the child's head differed altogether in its conformation from any Neanderthal skull so far discovered. The cerebellar lobes were set widely apart, so that when the skull is viewed from behind there is a pronounced lateral fullness or bulge-as in the skulls of young anthropoid apes. There were also certain features which recalled modern rather than Neanderthal man. It became important to remove from the interior of the skullits walls are only $3 \mathrm{~mm}$. in thickness-the hard mass of rock which filled it. This was successfully done by Mr. McCown and a cast was taken of the interior, and thus an exact reproduction of the shape of the brain was obtained. The position of the cerebellar lobes and of the overlying occipital lobes are quite different from the arrangement of parts seen in any known race of mankind.

It therefore became more than ever important that the adult form of the Neanderthal Palestinians should be discovered. The expedition for the present year was timed to set out at the end of March, but owing to Miss Garrod's illness, Mr. McCown had to return alone to resume the excavation of the rock-shelter at Mount Carmel. The cablegram just received announces his success, and justifies the assumption that he is now in a position to determine the racial characteristics of the Neanderthal Palestinians. The stratum at the rock-shelter represents upper or later Mousterian deposits.

\title{
Obituary
}

\section{Sir Patrick Geddes}

GIR PATRICK GEDDES died at the Collège des Écossais, Montpellier, on Sunday, April 17, at seventy-seven years of age, but still as full of ideas and enthusiasms as a young man. He was born in Perth in 1854, the son of Capt. Alexander Geddes, of the Black Watch, and he retained throughout life his feeling for the Highlands and their memories and survivals of the days before industrialism. Inspired by Darwin's work, he came to study under Huxley, but his primary interest was in the application of Darwinian ideas to the problems of human society, and he increasingly turned to the ideas of Lamarck, Herbert Spencer, and Auguste Comte, and realised his kinship of thought with Bergson. His thoughts were turned in this direction partly through a threat of blindness which, while he was carrying out research in Mexico, made microscope work impossible and forced him to live in a darkened room. Like Weismann in similar circumstances, he turned to thought and its graphical expression in highly suggestive notation systems.

In biology, Geddes was deeply concerned with ideas of metabolic tides in the organism, and saw plants, animals, and men as incarnations of vital activity fitting the expression of inner needs and urges into the frame of an outer environment that their activity was ever altering. Applications of this point of view to society led him to become the inspiration of the Sociological Society, the apostle of regional and town planning, the friend and counsellor of Herbertson in his geographical efforts at Oxford, the planner of the University of Jerusalem, a suggestive psychologist, and, above all, an interpreter quick to seize important points in the thought of other men and to respond with suggestions of relations that they might not have perceived. For, in a generation bent on analysis, he was ever seeking synthesis and pressing it forward with his overwhelming physical and mental vigour touched by mystical idealism. To try to help fellow-workers to maintain freshness, he first developed the idea of summer schools, which have become such a feature of educational and research efforts; he interested himself in exhibitions, and all but carried through a magnificent scheme in connexion with the Paris Exhibition of 1900 , spoiled in the end by a political crisis arising out of the Dreyfus case. He struggled to express and exhibit in his ' Outlook Tower' at Edinburgh his ideas of synthesis, and many a worker has found there, despite its poverty of resources and resulting inadequacies, a stimulus that has never been lost. A large collection of maps and illustrations relating to the evolution of cities was sunk, during the War, on a journey to Madras.

The partnership of Patrick Geddes and J. Arthur Thomson was as picturesque as it was valuable to other thinkers. Their "Evolution of Sex", their little book on "Evolution" in the Home Úniversity Library, and their recent instalment of a large work, were all efforts to express a much-needed point of view. In his other partnership, with Victor Branford, Geddes sought in a series of books and articles to give a synthetic view of social evolution. But publication and matters of personal fame in scientific work were always secondary to the desire to help men to understand their environments and

$$
\text { No. 3263, VoL. 129] }
$$


adjust them in such a way as to meet the need, not for immediate gain so much as for an enduring advance from which future generations might gain enhanced opportunities of expression of the best aspects of their personalities. His civic improvements at Edinburgh, his betterment of Indian cities, his efforts for residential halls for British students in French universities with the view of international understanding, and, perhaps most intimately of all, his gardens, were all the expression of the idealism that was the dominant note in a noble character.

\section{DR. L. A. BAUER}

Dr. Louis Agricola Bauer, who was killed on April 12, by falling from a window of his flat in Washington, was probably the best-known authority on terrestrial magnetism in the world. Born in Cincinnati, on Jan. 26, 1865, he was educated at the university there, and in Berlin. From 1887 until 1892 he was astronomer and magnetic computer in the U.S. Coast and Geodetic Survey, and in 1895-96 was an assistant to Michelson at Chicago. There he founded the journal Terrestrial Magnetism (the words and Atmospheric Electricity being added to the title in 1898) ; this was then, and still is, the only periodical expressly devoted to the subject. He conducted the journal for many years on his own financial responsibility, occasionally assisted by grants.

In 1896, Dr. Bauer began a magnetic survey of Maryland, under the State geologist-this was the only State magnetic survey that had been undertaken for many years; he continued the survey during two or three summer vacations, and published a very interesting historical account of terrestrial magnetic observation in his first report on the Survey. In 1897 he became assistant professor of mathematics and mathematical physics at Cincinnati. His enthusiasm for terrestrial magnetism, and his energetic pursuit of magnetic work, aroused renewed interest in the subject in the United States, and in 1899 he rejoined the Coast and Geodetic Survey as chief of the newly founded Division of TerrestrialMagnetism. Thereheinitiated an active policy, planning a magnetic survey of the whole of the United States and its territories elsewhere, and, in connexion therewith, instituting four new magnetic observatories, at Cheltenham in Maryland, Baldwin in Kansas, Sitka in Alaska, and Honolulu in Hawaii. He also greatly developed the magnetic work of the ships of the Coast and Geodetic Survey. Though he did not long remain in his new office, his influence on the work of the Coast and Geodetic Survey has been lasting, and the Survey is now one of the most active national organisations undertaking magnetic observatory and survey work.

Bauer's ambitions for his chosen science did not stop short at national frontiers, however; he saw that the science needed a world magnetic survey, and that, on account of the irregular and incalculable course of the secular variation, this survey must be renewed every generation, unless important data are to be for ever lost. He saw also that this could not be achieved by national organisations, so many countries being scientifically backward, while many parts of the oceans had long remained unsurveyed. He therefore drew up a plan for a research department of terrestrial magnetism, which should fill up what was lacking in the efforts made by other magnetic organisations, as regards the world survey, and also do everything possible in other ways to advance the science. His plans led to the formation of the Department of Terrestrial Magnetism of the Carnegie Institution of Washing ton, in 1904; he became the first director, and held the office until he retired through ill-health, in 1930. Under his energetic direction, and with the aid of a devoted staff that he gathered round him, the Department has done a great work for terrestrial magnetism and atmospheric electricity. Perhaps its most important work was done by its two survey ships, first the Galilee, and later the non-magnetic ship Carnegie (unhappily destroyed, with the loss of its commander, Capt. Ault, in 1929, at Apia, Samoa). Much land magnetic surveying was also done, either directly or by aid given to other bodies. Iater the Department instituted two magnetic observatories, at Watheroo in Western Australia and Huancayo in Peru, to mitigate the pressing need for more magnetic observatories in the southern hemisphere. A valuable feature of the ocean survey work was the promptness of publication of the results, which enabled the various national ocean magnetic charts to be greatly improved in many respects. In many other directions also the Department carried out important work, which is still continuing and developing.

In his attempts to elucidate the theoretical aspects of the science Bauer was less successful, but it is well known that the subject is a particularly intractable one. His organising work, and its valuable and permanent results, will assure him a lasting and distinguished place in the roll of benefactors to the science; and his services to it were widely recognised in his lifetime, particularly by his election, in 1927, to the presidency of the international organisation for terrestrial magnetism, under the International Union for Geodesy and Geophysics.

S. C.

\section{We regret to announce the following deaths :}

Mr. B. A. Behrend, consulting engineer to the Westinghouse Electric and Manufacturing Co., Boston, Mass., a distinguished American engineer interested particularly in alternating current phenomena, on March 25, aged fifty-six years.

Sir David Drummond, C.B.E., emeritus professor of medicine at the University of Durham College of Medicine, past president of the British Medical Association, a well-known specialist in diseases of the brain, on April 27, aged seventy-nine years.

Dr. Victoria Hazlitt, lecturer in psychology, Bedford College, University of London, for some years secretary of the Committee for Research in Education of the British Psychological Society, on April 19.

$$
\text { No. 3263, Vou. 129] }
$$

